\title{
Substitusi Kuning Telur dengan Lesitin Kedelai sebagai Pengencer Semen dalam Mempertahankan Kualitas Spermatozoa Kerbau Penyimpanan $5^{\circ} \mathrm{C}$
}

\author{
Nisfu Saaban', Chairussyuhur Arman², Enny Yuliani² dan Maskur ${ }^{2}$ \\ ${ }^{1}$ Program Studi Magister Manajemen Sumberdaya Peternakan, Fakultas Peternakan \\ Universitas Mataram \\ ${ }^{2}$ Fakultas Peternakan Universitas Mataram \\ J1. Majapahit No.62 Mataram Lombok Nusa Tenggara Barat 83125 \\ *Email korespondensi: nisfu2016@yahoo.com
}

(Diterima: 27-07-2019; disetujui 25-08-2019)

\begin{abstract}
ABSTRAK
Pengencer konvensional berbasis kuning telur yang bersumber dari hewan membawa risiko kontaminasi mikroba dan menghalangi jarak pandang pemeriksaan spermatozoa di bawah mikroskop. Penelitian ini dilaksanakan` untuk menilai apakah substitusi kuning telur dengan lesitin kedelai di dalam pengencer berbasis-tris dapat mempertahankan kualitas spermatozoa kerbau lumpur pada penyimpanan $5^{\circ} \mathrm{C}$ selama 120 jam. Ejakulat dari 3 ekor kerbau umur 3-4 tahun dengan bobot badan $450-500 \mathrm{~kg}$ ditampung dengan menggunakan vagina buatan.Semen diencerkan dengan pengencer konvensional yang mengandung 20\% kuning telur (kontrol) dan pengencer lesitin dengan konsentrasi1\%, 2\%, 3\% dan $4 \%$ (perlakuan) dan disimpan pada $5^{\circ} \mathrm{C}$ selama 120 jam. Parameter spermatozoa dinilai pada interval 0 , 72, dan 120 jam setelah semen yang diencerkan disimpan $5^{\circ}$ C.Persentase motilitas dan spermatozoa normal tidak berbeda nyata $(\mathrm{P}<0,05)$ antara pengencer $1 \%$ lesitin dan kontrol. Namun pengencer $1 \%$ lesitin mampu mempertahankan kedua parameter tersebut setelah penyimpanan $5^{\circ} \mathrm{C}$ selama $120 \mathrm{jam}$. Persentase viabilitas, keutuhan membran dan tudung akrosom spermatozoa pada pengencer $1 \%$ lesitin dibandingkan pengencer kontrol lebih tinggi $(\mathrm{P}<0,05)$ dari pengencer perlakuan 2 , 3, dan $4 \%$ lesitin. Disimpulkan bahwa pengencer $1 \%$ lesitin dapat menyubstitusi pengencer konvensional berbasis kuning telur untuk penyimpanan semen kerbau pada $5^{\circ} \mathrm{C}$ selama $120 \mathrm{jam}$.
\end{abstract}

Kata kunci: kuning telur, lesitin, pengencer, semen cair, semen kerbau

\begin{abstract}
Conventional egg yolk-based diluent animal origin carries the risk of microbial contamination and interference with microscopic examination. This study was conducted to assess whether substitution of egg yolk with soy lecithin in tris-based diluents can maintain the quality of buffalo spermatozoa stored at $5^{\circ} \mathrm{C}$ for $120 \mathrm{~h}$. Ejaculate from 3 buffaloes aged 3-4 years and body weight of $450-500 \mathrm{~kg}$ was collected using an artificial vagina. Semen was diluted with diluent containing $20 \%$ egg yolk (control) and diluent with concentrations of lecithin 1\%,2\%,3\% and 4\% (treatment). Spermatozoa parameters were assessed at intervals of 0,72 and $120 \mathrm{~h}$ after the diluted semen was stored at $5^{\circ} \mathrm{C}$ for $120 \mathrm{~h}$. The percentages of motility and normal spermatozoa did not differ significantly $(\mathrm{P}<0.05)$ between $1 \%$ lecithin and control diluents. However, $1 \%$ of lecithin was able to maintain both parameters after stored at $5^{\circ} \mathrm{C}$ for $120 \mathrm{~h}$. The percentages of viability, membrane integrity and functional acrosome of spermatozoa in $1 \%$ lecithin were higher $(\mathrm{P}<0.05)$ than control and the other three treatment diluents. In conclusion, $1 \%$ of lecithin diluent could substitute conventional egg yolk-based diluent for the storage of buffalo semen at $5^{\circ} \mathrm{C}$ for $120 \mathrm{~h}$.
\end{abstract}

Keywords: buffalo semen, egg yolk, lecithin, diluents, liquid semen 


\section{PENDAHULUAN}

Inseminasi buatan (IB) pada ternak kerbau merupakan teknologi reproduksi yang efisien untuk perbaikan genetik dan juga manajemen reproduksi. Salah satu tahapan penting dalam IB pada kerbau adalah pengawetan (preservasi) semen, baik untuk tujuan penyimpanan jangka pendek dalam bentuk cair maupun jangka panjang dalam keadaan beku (Maxwell \& Watson, 1996). Proses pembekuan dan pencairan kembali (thawing) semen kerbau akan menyebabkan kerusakan yang lebih besar pada spermatozoa bila dibandingkan dengan penyimpanan dalam kondisi cair (Mostafa et al., (2018). Inseminasi buatan pada kerbau menggunakan semen beku belum berhasil sepenuhnya menunjukkan kesuburan yang baik, kemungkinan besar karena daya-bekunya yang buruk dan tingkat kesuburan spermatozoanya yang lebih rendah dibandingkan spermatozoa sapi (Kumaresan et al., 2005).

Mostafa et al. (2018) melaporkan bahwa penurunan sekitar 50\% motilitas spermatozoa, daya hidup dan status membran spermatozoa merupakan masalah utama yang terjadi selama proses pembekuan semen akibat kerusakan hebat pada membran plasma selama proses pembekuan. Sebaliknya, menurut Vishwanath \& Shannon (2000) keuntungan semen cair yaitu prosesnya lebih mudah dan dapat digunakan pada lokasi yang cukup jauh karena spermatozoa bisa bertahan 2 sampai 4 hari. Meskipun, semen dingin memiliki kelemahan yaitu jangka hidupnya relatif singkat, namun secara teknis lebih mudah daripada semen beku, dan pengirimannya menghemat biaya. Efek utama yang menguntungkan dari penyimpanan dingin $\left(5^{\circ} \mathrm{C}\right)$ adalah kemampuannya menurun-kan kecepatan metabolisme sperma-tozoa sehingga berkontribusi dalam memper-panjang viabilitas sel (Vishwanath \& Shannon, 2000).

Keberhasilan penyimpanan spermatozoa dalam semen yang disimpan cair (liquid storage) tergantung pada penurunan motilitas yang dapat pulih kembali (reversible) dan aktivitas metabolisme spermatozoa, sehingga memperpanjang kehidupan suburnya. Hal ini dicapai dengan cara menyimpan semen pada suhu rendah $\left(5^{\circ} \mathrm{C}\right.$ dan $\left.15^{\circ} \mathrm{C}\right)$ dan di dalam pengencer-pengencer yang mengandung unsurunsur yang mampu menunda terproduksinya reactive oxygen species/ROS) oleh spermatozoa (de Paz et al., 2010).

Banyak macam pengencer yang digunakan untuk pengawetan semen kerbau, namun demikian pengencer berbasis Tris-kuning telur adalah yang paling banyak digunakan dan memberikan hasil yang memuaskan dalam penyimpanan semen kerbau (Ahmad, 2014). Komponen yang efektif di dalam kuning telur adalah lipoprotein densitas rendah (LDL) dan fosfolipid seperti fosfatidikolin yang mampu mempertahankan dan mencegah membran sperma terhadap kejutan dingin (cold shock) (Bergeron et al., 2004).

Pengencer semen berbasis-Tris umumnya menambahkan kuning telur hingga 20\% sehingga meningkatkan risiko kontaminasi mikroba yang mengarah pada terproduksikannya endotoksin-endotoksin tertentu dan akibatnya menurunkan potensi daya pembuahan spermatozoa (Aires et al., 2003). Oleh karena itu, pengencer yang bukan berasal dari produk hewan, terformulasikan dengan baik dan bebas patogen sebagai pengganti pengencer berbasis kuning telur menjadi pilihan yang lebih disukai. Salah satu produk non-hewan dan berasal dari tanaman adalah kedelai. Kedelai mengandung LDL dalam jumlah besar yang disebut lesitin kedelai, mirip dengan lesitin kuning telur, dan juga mengandung asam-asam lemak seperti asam stearat, oleat, dan palmitat yang memiliki potensi melindungi membran plasma selama kriopreservasi semen (Chaudhari et al., 2015).

Berbagai persentase lesitin kedelai telah digunakan dalam pengencer untuk pengawetan semen. Pada spesies seperti domba (Forouzanfar et al. 2010) atau kambing (Salmani et al., 2014), sebanyak $0.5-2.5 \%$ lesitin digunakan untuk membandingkan dengan pengencer yang mengandung 15-20\% kuning telur. Kmenta et al. (2011) melaporkan penggunaan $0.8 \%$ lesitin kedelai untuk penyimpanan cair dingin semen anjing sedangkan Vick et al. (2012) menggunakan $1 \%$ lesitin dalam pengencer untuk kriopreservasi semen kucing. Pada kelinci, pemakaian lesitin 1,5\% merupakan konsentrasi optimum untuk kriopreservasi semen (Nishijima et al., 2015). Singh et al. (2012) menambahakan berbagai persentase susu kedelai $(10 \%, 15 \%$, $20 \%, 25 \%$ dan $30 \%$ ) dalam pengencer tris dan membandingkannya dengan pengencer konvensional tris-kuning telur untuk penyimpanan dingin semen kerbau Murrah selama 72 jam. 
Penelitian penyimpanan semen dingin di dalam pengencer Tris berbasis-lesitin kedelai pada kerbau lumpur yang tersedia dalam literatur masih sangat terbatas. Oleh karena itu, penelitian untuk menilai apakah substitusi kuning telur dengan lesitin kedelai di dalam pengencer berbasis-tris dapat mempertahankan kualitas spermatozoa kerbau lumpur (Bubalus bubalis) pada penyimpanan $5^{\circ} \mathrm{C}$ selama $120 \mathrm{jam}$.

\section{MATERI DAN METODE}

\section{Penampungan dan penilaian awal}

Tiga ekor kerbau lumpur (Bubalus bubalis) yang berumur antara 3 sampai 4 tahun dengan bobot badan sekitar 450 sampai $500 \mathrm{~kg}$ yang dipelihara di Teaching Farm Universitas Mataram digunakan dalam penelitian sebagai sumber semen. Ejakulat semen ditampung dari setiap kerbau jantan menggunakan vagina buatan $\left(42^{\circ} \mathrm{C}\right)$ seminggu sekali selama 4 minggu berturut-turut. Semen dibawa ke laboratorium dalam waktu 30 menit setelah penampungan $(37 \circ \mathrm{C})$.

Sampel semen segar dievaluasi secara makroskopis (volume, pH, warna dan konsistensi) dan mikroskopis (motilitas massa, motilitas individu, konsentrasi, viabilitas dan morfologi spermatozoa). Sampel semen segar yang menunjukkan motilitas individu spermatozoa minimal 70\%dan morfologi normal spermatozoa $80 \%$ diencerkan dengan pengencer semen untuk penyimpanan dingin/ chilled semen $\left(5^{\circ} \mathrm{C}\right)$.

\section{Pemrosesan semen}

Pengencer semen berbasis Tris: Tris-asam sitrat-fruktosa dengan kuning telur (KT) dan tanpa kuning telur namun disubstitusi dengan lesitin kedelai (LK) dipersiapkansehari sebelum koleksi semen dan disimpan dalam refrigerator. Sampel semen dibagi menjadi lima bagian yang sama, setiap bagian diencerkan dengan lima pengencer yang berbeda: KT 20\% (kontrol), LK $1 \%$, LK 2\%, LK $3 \%$ dan LK 4\%.Sampel semen diencerkandengan rasio 1:2 (semen:pengencer) di dalam penangas air $\left(32^{\circ} \mathrm{C}\right)$. Semen yang telah diencerkan didinginkan secara perlahan hingga mencapai $5^{\circ} \mathrm{C}$ selama 2 jam.Semendingin (chilled semen) dari masing-masing perlakuan dievaluasi pada interval 0,72 dan 120 jam untuk parameter kualitas spermatozoa (motilitas, viabilitas, morfologi normal, keutuhan membran plasma dan keutuhan tudung akrosom).

\section{Penilaian semen dingin $\left(5^{\circ} \mathrm{C}\right)$ \\ Motilitas individu spermatozoa}

Motilitas individu spermatozoa dinilai dengan menggunakan mikroskop cahaya pada perbesaran 400 kali. Sebanyak $10 \mu \mathrm{l}$ semen dingin diletakkan di atas slide kaca $\left(37^{\circ} \mathrm{C}\right)$ dan ditutup dengan kaca penututp (coverslip). Sperma yang menunjukkan pergerakan progresif dinilai dari sedikitnya lima bidang pandang mikroskop yang dipilih secara acak. Total 100 sel dihitung per slide.

\section{Viabilitas dan normalitas spermatozoa}

Viabilitas dan persentase morfologi normal spermatozoa ditentukan menggunakan pewarnaan eosin-nigrosin (EN).Sebanyak $10 \mu \mathrm{L}$ semen dingin diteteskan di atas slide kaca dan dicampur dengan $20 \mu \mathrm{L}$ EN sampai merata, kemudian dibuat smear (pulasan) tipis, dibiarkan mengering di atas penghangat gelas objek $\left(45^{\circ} \mathrm{C}\right)$. Selanjutnyagelas objek (slide) diperiksa di bawah mikroskop perbesaran 400 kali untuk penilaian viabilitas spermatozoa. Spermatozoa yang terwarnai merah muda dianggap mati, dan yang tidak terwarnai dianggap hidup.

Penentuan morfologi dilakukan dengan mengamati bentuk spermatozoa dengan (1) morfologi normal, (2) ekor bengkok, (3) ekor putus dan (4) ekor melingkar. Sebanyak 100 spermatozoa dipilih secara acak dari lima lapang pandang mikroskop perbesaran 400 kali dievaluasi untuk setiap gelas objek.

\section{Keutuhan membran plasma}

Hypo-Osmotic Swelling Test (HOST) telah terbukti menjadi alat yang baik untuk mengevaluasi keutuhan fungsional membran spermatozoa berdasarkan pada bentuk ekor melingkar dan membengkak. Pemeriksaan membran plasma spermatozoa dilakukan dengan menggunakan larutan HOST (sitrat dan fruktosa). Sebanyak $100 \mu$ sampel semen dicampurkan dengan $500 \mu$ larutan hypoosmotic diinkubasi dalam penangas air $\left(37^{\circ} \mathrm{C}\right)$ selama 60 menit. Sesudah inkubasi, sebanyak $10 \mu 1$ sampel semen diletakkan di atas gelas slide ditutup cover slip. Selanjutnya gelas objek diperiksa di bawah mikroskop dengan perbesaran 400 kali pada lima lapang pandang yang dipilih secara acak. Total 100 sel dihitung per slide.Membran plasma spermatozoa yang utuh (HOS-test positip) dicirikan oleh ekor yang melingkar dan menggelembung sedang-kan yang tidak utuh (HOS-test negatif) ditunjukkan oleh 
spermatozoa yang ekornya tidak melingkar dan menggelembung.

\section{Keutuhan tudung akrosom}

Pemeriksaan tudung akrosom dilakukan dengan menggunakan campuran larutan $1 \%$ (v/v) formaldehyde komersial dan $2.9 \%(\mathrm{w} / \mathrm{v})$ larutan Tri-sodium citrate dehydrate. Kemudian $500 \mu$ campuran larutan ini dicampurkan dengan $100 \mu$ sampel semen dingin dan selanjutnya sebanyak $10 \mu \mathrm{l}$ diteteskan di atas obyek gelas, ditutup dengan coverslip dan diberi minyak imersi. Keutuhan tudung akrosom dicirikan oleh pinggir apikal yang normal (normal apical ridge). Sebanyak 100 spermatozoa dihitung dibawah mikroskop perbesaran 1000 kali pada 5 lapang pandang dipilih secara acak.

\section{Analisis statistik}

Data dianalisis menggunakan rancangan acak lengkap (RAL) pola faktorial untuk menghitungAnalysis of Variance (ANOVA) dan dilanjutkan uji Duncan'S Multiple Range Test (DMRT) untuk menentukan perbedaan yang signifikan pada semua parameter di antara berbagai perlakuan menggunakan software SPSS. Perbedaan dengan nilai $\mathrm{P}<0.05$ dinyatakan signifikan secara statistik.

\section{HASIL PENELITIAN}

Parameter kualitas spermatozoa seperti persentase motilitas, morfologi normal, keutuhan membran (HOST), dan keutuhan tudung akrosom spermatozoa kerbau lumpur yang diencerkan dalam pengencer yang mengandung 20\% kuning telur (kontrol) dan pengencer yang mengandung lesitin kedelai (LK) dengan berbagai konsentrasi (LK 1\%, LK $2 \%$, LK $3 \%$, dan LK $1 \%$ ) pada penyimpanan $5^{\circ} \mathrm{C}$ selama 120 jam dinilai dan hasilnya ditunjukkan pada Tabel 1. Interaksi antara pengencer semen dengan waktu penyimpanan didapati tidak signifikan $(\mathrm{p}<0,05)$ untuk semua parameter kualitas spermatozoa. Namun demikian, baik pengaruh pengaruh pengencer semen maupun waktu penyimpanan terhadap berbagai parameter kualitas spermatozoa didapati signifikan $(\mathrm{p}<0,05)$.

\section{Motilitas}

Motilitas spermatozoa setelah pengenceran dan penyimpanan semen dingin $\left(5^{\circ} \mathrm{C}\right)$ tidak menunjukkan perbedaan signifikan $(p>0,05)$ antara pengencer yang mengandung lesitin $1 \%$ dan kontrol. Namun motilitas spermatozoa menurun secara nyata $(\mathrm{p}<0,05)$ pada semua pengencer selama penyimpanan 0,72 dan 120 jam.Motilitas individu spermatozoa lebih tinggi $(\mathrm{p}<0,05)$ pada pengencer lesitin $1 \%$ dibandingkan lesitin 2, 3 dan 4\%. Adapun motilitas spermatozoa di antara ketiga pengencer terakhir tidak berbeda nyata $(p>0.05)$. Demikian pula motilitas di dalam pengencer kontrol, secara statistik tidak berbeda $(p>0.05)$ dengan pengencer lesitin 3 dan 4\%. Akan tetapi, pengencer kontrol menunjukkan motilitas yang lebih tinggi $(\mathrm{p}<0.05)$ daripada pengencer lesitin $4 \%$.

\section{Viabilitas}

Persentase viabilitas spermatozoa segera setelah pengenceran dan penyimpanan semen dingin selama 0 dan 72 jam tidak menunjukkan penurunan yang signifikan $(p>0,05)$ untuk semua pengencer. Namun setelah 120 jam penyimpanan, penurunan persentase viabilitas spermatozoa terjadi sangat signifikan pada kelima pengencer. Daya hidup spermatozoa di dalam pengencer lesitin $1 \%$ didapati berbeda nyata $(p>0,05)$ dengan pengencer lesitin $2,3,4 \%$ dan kontrol.

\section{Morfologi normal}

Persentase spermatozoa yang menunjukkan morfologi normal tidak berbeda nyata $(p>0,05)$ setelah pengenceran dan penyimpanan $5^{\circ} \mathrm{C}$ antara pengencer lesitin $1 \%$ dan kuning telur 20\% (kontrol). Akan tetapi, perbedaan persentase spermatozoa normal di dalam kedua pengencer tersebut dengan pengencer lesitin 2, 3, dan 4\% didapati signifikansi $(\mathrm{p}<0,05)$. Proporsi spermatozoa yang secara morfologi normal terjadi penurunan secara nyata $(\mathrm{p}<0,05)$ sejalan dengan waktu penyimpanan semen dingin.

\section{Keutuhan membran plasma}

Persentase keutuhan membran plasma spermatozoa kerbau yang dicirikan dari ekor melingkar dan menggelembung didapati lebih tinggi( $p>0.05)$ di dalam pengencer berisi lesitin $1 \%$ dibandingkan keempat pengencer lainnya. Meskipun tidak terdapat perbedaan yang nyata ( $>0.05$ ) keutuhan membran plasma di antara pengencer lesitin 2,3 , dan $4 \%$, namun perbedaan antara pengencer kontrol dan lesitin 3\% adalah signifikan $(\mathrm{p}<0,05)$. Persentase 
Tabel 1. Persentase motilitas, viabilitas, morfologi normal, keutuhan membran plasma dan keutuhan tudung akrosom spermatozoa kerbau lumpur yang diencerkan di dalam pengencer kontrol, lesitin $1 \%$, lesitin $2 \%$, lesitin $3 \%$ dan lesitin $4 \%$ pada penyimpanan $5^{\circ} \mathrm{C}$ selama 120 jam (Rataan \pm SD)

\begin{tabular}{|c|c|c|c|c|c|c|}
\hline Waktu & Parameter & KT $20 \%$ & LK $1 \%$ & LK $2 \%$ & LK $3 \%$ & LK 4\% \\
\hline \multirow[t]{5}{*}{0} & $\%$ Motilitas & $78,18 \pm 3,37^{\mathrm{aAC}}$ & $78,64 \pm 2,34^{\mathrm{aA}}$ & $75,91 \pm 9,17^{\mathrm{aB}}$ & $73,64 \pm 8,39^{\mathrm{aB}}$ & $70,91 \pm 17,15^{\mathrm{aBD}}$ \\
\hline & $\%$ Viabilitas & $81,73 \pm 3,69^{\mathrm{aB}}$ & $85,73 \pm 3,10^{\mathrm{aA}}$ & $82,82 \pm 2,71^{\mathrm{aB}}$ & $80,45 \pm 2,38^{\mathrm{aB}}$ & $79,55 \pm 4,72^{\mathrm{aB}}$ \\
\hline & $\%$ Morfologi & $88,45 \pm 2,91^{\mathrm{aA}}$ & $88,73 \pm 4,17^{\mathrm{aA}}$ & $85,91 \pm 4,25^{\mathrm{aB}}$ & $86,73 \pm 2,69^{\mathrm{aB}}$ & $86,55 \pm 4,41^{\mathrm{aB}}$ \\
\hline & $\% \mathrm{KMP}$ & $86,64 \pm 7,24^{\mathrm{aBC}}$ & $89,36 \pm 5,50^{\mathrm{aA}}$ & $85,45 \pm 6,20^{\mathrm{aB}}$ & $83,82 \pm 7,44^{\mathrm{aBD}}$ & $82,55 \pm 5,99^{\mathrm{aB}}$ \\
\hline & $\% \mathrm{KTA}$ & $82,73 \pm 6,99^{\mathrm{aB}}$ & $87,73 \pm 5,02^{\mathrm{aA}}$ & $86,45 \pm 4,99^{\mathrm{aB}}$ & $84,91 \pm 7,26^{\mathrm{aA}}$ & $85,45 \pm 3,91^{\mathrm{aA}}$ \\
\hline \multirow[t]{5}{*}{72} & $\%$ Motilitas & $57,27 \pm 29,53^{\mathrm{bAC}}$ & $66,36 \pm 13,25^{\mathrm{bA}}$ & $52,73 \pm 27,51^{\mathrm{bB}}$ & $52,27 \pm 25,33^{\mathrm{bB}}$ & $42,27 \pm 33,49^{\mathrm{bBD}}$ \\
\hline & $\%$ Viabilitas & $80,82 \pm 9,00^{\mathrm{aB}}$ & $85,18 \pm 5,69^{\mathrm{aA}}$ & $81,27 \pm 7,67^{\mathrm{aB}}$ & $80,45 \pm 7,54^{\mathrm{aB}}$ & $81,27 \pm 7,31^{\mathrm{aB}}$ \\
\hline & $\%$ Morfologi & $86,36 \pm 3,11^{\mathrm{bA}}$ & $87,55 \pm 2,98^{\mathrm{bA}}$ & $85,18 \pm 1,60^{\mathrm{bB}}$ & $83,27 \pm 3,55^{\mathrm{bB}}$ & $85,55 \pm 2,84^{\mathrm{bB}}$ \\
\hline & $\% \mathrm{KMP}$ & $78,18 \pm 6,00^{\mathrm{bBC}}$ & $84,09 \pm 3,70^{\mathrm{bA}}$ & $74,82 \pm 9,84^{\mathrm{bB}}$ & $75,45 \pm 7,27^{\mathrm{bBD}}$ & $75,27 \pm 6,33^{\mathrm{bB}}$ \\
\hline & $\% \mathrm{KTA}$ & $76,09 \pm 9,24^{\mathrm{bB}}$ & $80,00 \pm 7,54^{\mathrm{bA}}$ & $72,00 \pm 12,21^{\mathrm{bB}}$ & $77,64 \pm 7,88^{\mathrm{bA}}$ & $76,00 \pm 7,44^{\mathrm{bA}}$ \\
\hline \multirow[t]{5}{*}{120} & $\%$ Motilitas & $25,00 \pm 24,19^{\mathrm{cAC}}$ & $30,91 \pm 20,71^{\mathrm{cA}}$ & $10,91 \pm 13,75^{\mathrm{cB}}$ & $12,73 \pm 15,55^{\mathrm{cB}}$ & $12,27 \pm 17,52^{\mathrm{cBD}}$ \\
\hline & $\%$ Viabilitas & $72,91 \pm 13,66^{\mathrm{bB}}$ & $77,91 \pm 10,77^{\mathrm{bA}}$ & $72,00 \pm 10,98^{\mathrm{bB}}$ & $73,91 \pm 12,38^{\mathrm{bB}}$ & $69,27 \pm 12,88^{\mathrm{bB}}$ \\
\hline & $\%$ Morfologi & $83,27 \pm 2,76^{\mathrm{cA}}$ & $85,00 \pm 2,05^{\mathrm{cA}}$ & $82,91 \pm 3,91^{\mathrm{cB}}$ & $85,09 \pm 2,77^{\mathrm{cB}}$ & $82,91 \pm 2,39^{\mathrm{cB}}$ \\
\hline & $\% \mathrm{KMP}$ & $68,09 \pm 12,28^{\mathrm{cBC}}$ & $73,45 \pm 9,31^{\mathrm{cA}}$ & $66,18 \pm 13,17^{\mathrm{cB}}$ & $58,82 \pm 15,03^{\mathrm{cBD}}$ & $61,55 \pm 13,35^{\mathrm{cB}}$ \\
\hline & $\% \mathrm{KTA}$ & $72,18 \pm 7,99^{\mathrm{bB}}$ & $78,73 \pm 3,95^{\mathrm{bA}}$ & $71,91 \pm 10,04^{\mathrm{bB}}$ & $74,45 \pm 6,02^{\mathrm{bA}}$ & $73,09 \pm 10,62^{\mathrm{bA}}$ \\
\hline
\end{tabular}

KT, kuning telur. LK, lesitin kedelai. KMP, keutuhan membran plasma. KTA, keutuhan tudung akrosom.

Huruf yang berbeda menunjukkan perbedaan yang signifikan ( $\mathrm{p}<0,05)$. Angka dengan huruf kecil di dalam kolom berbeda secara signifikan $(\mathrm{p}<0,05)$, dan angka dengan huruf besar di dalam baris berbeda secara signifikan $(\mathrm{p}<0,05)$

keutuhan membran spermatozoa menurun secara nyata $(\mathrm{p}<0,05)$ dengan bertambahnya waktu penyimpanan.

\section{Keutuhan tudung akrosom}

Persentase keutuhan tudung akrosom spermatozoa secara signifikan $(\mathrm{p}<0,05)$ menurun lebih cepat pada pengencer kontrol dan pengencer lesitin 2\% dibandingkan dengan pengencer lesitin $1 \%$. Persentase akrosom utuh didapati berbeda nyata $(\mathrm{p}<0,05)$ antara penyimpanan 0 jam dengan 72 dan 120 jam, namun antara penyimpanan 72 dan 120 jam perbedaannya tidak signifikan ( $p>0,05)$.

\section{PEMBAHASAN}

Pengencer berbasis Tris-kuning telur umumnya digunakan untuk pengawetan semen beku dan penyimpanan cair-dingin semen kerbau. Selama penyimpanan cair-dingin, spermatozoa kerbau mengalamikejutan dingin (cold shock) dan kerusakan struktur sehingga menurunkan motilitas spermatozoa, dan kecepatan penurunannya tergantung pada waktu penyimpanan (Bucak dan Tekin, 2007).

Persentase motilitas spermatozoa di dalam pengencer berbasis-lesitin dan kuning telur mampu dipertahankan antara 42 sampai $66 \%$ setelah penyimpanan 72 jam dan setelah penyimpanan 120 jam, motilitas menurun dengan cepat lebih dari separuhnya yaitu 12 sampai $30 \%$ (Tabel 1). Pada penyimpanan 72 jam, motilitas tertinggi $(66,36 \%)$ didapati pada pengencer yang mengandung $1 \%$ lesitin dibandingkan ketiga konsentrasi lesitin lainnya. Meskipun kemampuan pengencer $1 \%$ lesitin dalam menjaga motilitas didapati lebih tinggi dibandingkan pengencer kontrol $(57,27 \%)$, namun perbedaan persentasenya tidak signifikan. Hal ini menunjukkan potensi lesitin kedelai yang mirip dengan lesitin kuning telur dalam melindungi membran spermatozoa setelah penyimpanan semen kerbau lumpur pada $5^{\circ} \mathrm{C}$ hingga 72 jam. Hasil ini didukung oleh penelitian Singh et al. (2012) yang melaporkan bahwa penggantian kuning telur dengan pengencer berbasis susu kedelai tidak menunjukkan penurunan yang signifikan dalam parameter motilitas spermatozoa kerbau Murrah yang disimpan selama 72 jam pada $5^{\circ} \mathrm{C}$.Akan tetapi hasil penelitian sekarang berbeda dengan hasil yang dilaporkan oleh Forouzanfar et al. (2010), bahwa motilitas spermatozoa domba di 
dalam pengencer yang mengandung $1 \%$ kedelai lebih tinggi dibandingkan dengan pengencer yang mengandung $20 \%$ kuning telur. Pada sisi lain, menurunnya motilitas spermatozoa di dalam pengencer yang konsentrasi lesitinnya lebih dari $1 \%$ kemungkinan pada konsentrasi lesitin yang lebih tinggi (2\% sampai $4 \%$ ) jarak pandang spermatozoa di bawah mikroskop menjadi rendah sebagaimana pengamatan pada pengencer kuning telur yang banyak gumpalan lemaknya (Forouzanfar et al., 2010). Menurut Hirai et al. (1997), pengurangan kecepatan gerak spermatozoadi dalam pengencer semen pada konsentrasi lesitin yang tinggi kemungkinan akibat tingginya viskositas pengencer. Persentase viabilitas spermatozoa kerbau lumpur di dalam kelima macam pengencer semen tidak mengalami banyak perubahan sampai dengan penyimpanan 72 jam dan rata-rata masih di atas $80 \%$. Namun dengan bertambahnya waktu penyimpanan hingga 120 jam, persentase spermatozoa hidup dengan akrosom utuh pada $5^{\circ} \mathrm{C}$ menurun secara nyata.

Kemampuan mempertahankan daya hidup spermatozoa tertinggi $(85 \%)$ ditunjukkan oleh pengencer semen dengan konsentrasi lesitin $1 \%$ daripada konsentrasi 2 sampai $4 \%$ dan kuning telur $20 \%$. Viabilitas dalam penelitian sekarang sejalan dengan hasil yang dilaporkan oleh Akhter et al. (2011), bahwa daya hidup spermatozoa kerbau dalam pengencer berbasis lesitin kedelai lebih baik dibandingkan pengencer susu, tris-sitrat kuning telur, dan kuning telur-sitrat pada penyimpanan $5^{\circ} \mathrm{C}$. Forouzanfar et al. (2010) juga melaporkan hasil yang sama pada semen domba yaitu lebih tingginya viabilitas spermatozoa dalam pengencer $1 \%$ lesitin daripada $20 \%$ kuning telur.Persentase spermatozoa yang secara morfologi normal didapati sebanding antara pengencer $1 \%$ lesitin $(85 \%)$ dan pengencer kontrol $(83,27 \%)$ sampai dengan penyimpanan 120 jam pada $5^{\circ} \mathrm{C}$. Penurunan jumlah spermatozoa normal cenderung terjadi dengan meningkatnya konsentrasi lesitin hingga $4 \%$. Hasil ini konsisten dengan hasil penelitian Rehman et al. (2014) yang menunjukkan adanya kesetaraan antara pengencer yang mengandung $25 \%$ susu kedelai dan pengencer dengan $20 \%$ kuning telur, namunjumlah spermatozoa normalmenurun ketika konsentrasi susu kedelai digandakan dari $25 \%$ menjadi $50 \%$.
Keutuhan membran plasma (HOST) spermatozoa kerbau di dalam pengencer lesitin $1 \%$ lebih tinggi dibandingkan lesitin 2, 3, 4\% dan kuning telur $20 \%$ sesudah penyimpanan $5^{\circ} \mathrm{C}$ selama 120 jam. Hal ini menunjukkan efek positip dari lesitin $1 \%$ selama preservasi semen cair-dingin. Adanya lesitin kedelai di dalam pengencer semen maka fosfolipid dari membran spermatozoa akan tergantikan oleh fosfolipid lesitin sehingga mampu memper-tahankan struktur dan fungsi membran sprmatozoa (Graham \& Foote, 1987). Fosfolipid dari kedelai dapat berintegrasi dengan membran spermatozoa untuk membentuk film (lapisan) pelindung terhadap faktor-faktor yang mematikan (Zhang et al., 2009). Konsentrasi lesitin di atas $1 \%$ menyebabkan terjadinya penurunan integrasi membran spermatozoa kerbau, dan kecenderungan yang sama diamati pula oleh Singh et al. (2012) pada semen kerbau yang disimpan $5^{\circ} \mathrm{C}$.

Ketika semen kerbau cair-dingin disimpan selama 120 jam pada $5^{\circ} \mathrm{C}$, pengencer yang mengandung lesitin $1 \%$ mampu mempertahankan keutuhan tudung akrosom spermatozoa lebih baik daripada pengencer dengan lesitin 2\% dan pengencer kontrol.Hasil ini sesuai dengan hasil terbaru yang didapatkan oleh Mostafa et al. (2018) bahwa, 1.0\% lesitin kedelai di dalam pengencer semen merupakan konsentrasi terbaik dalam mempertahankan keutuhan tudung akrosom spermatozoa kerbau selama pra-pembekuan dan proses ekuilibrasi selama 2 jam pada $5^{\circ} \mathrm{C}$.

\section{KESIMPULAN}

Penambahan lesitin sebanyak $1 \%$ di dalam pengencer semen berbasis-tris dapat menyubstitusi penggunaan pengencer konvensioanl tris-kuning telur $20 \%$ dalam mempertahankan parameter kualitas (motilitas, viabilitas, normalitas, keutuhan membran plasma dan keutuhan tudung akrosom) spermatozoa kerbau lumpur (Bubalus bubalis) yang disimpan pada $5^{\circ} \mathrm{C}$ selama $120 \mathrm{jam}$.

\section{DAFTAR PUSTAKA}

Ahmad, I., S.U. Jatoi, M. Zubair, \& M. Younis. 2014. Comparative efficacy of different cryoprotectants for deep freezing of buffalo bull semen. Adv. Anim. Vet. Sci.2:150-154. 
Aires, V.A., K.D. Hinsch, F.M. Schloesser, K. Bogner, S. M. Schloesser, \& E. Hinsch. 2003. In vitro and in vivo comparison of egg yolk-based and soybean lecithinbased extenders for cryopreservation of bovine semen. Theriogenology60:269279.

Akhter, S., B.A. Rakha, M.S. Ansari, S.M.H., Andrabi, \& N. Ullah. 2011. Storage of Nili-Ravi Buffalo (Bubalus bubalis) Semen in Skim Milk Extender Supplemented with Ascorbic Acid and $\alpha$ Tocopherol. Pakistan J. Zool. 43:273-277.

Bergeron, A., M.H.Crete, Y. Brindle, \& P. Manjunath. 2004. Low-density lipoprotein fraction from hen's egg yolk decreases the binding of the major proteins of bovine seminal plasma to sperm and prevents lipid efflux from the sperm membrane. Biol. Reprod. 70:708717.

Bucak, M.N. \& N. Tekin. 2007. Protective effect of taurine, glutathione and trehalose on the liquid storage of ram semen. Small Rumin. Res. 73:103-108.

Chaudhari, D.V., A.J. Dhami, K.K. Hadiya, \&Patel, J.A. 2015. Relative efficacy of egg yolk and soya milk-based extenders for cryopreservation $\left(-196^{\circ} \mathrm{C}\right)$ of buffalo semen. Vet. World 8:239-244.

De Paz, P., M.C. Esteso, M. Alvarez, M. Mata, C.A. Chamorro, \& L. Anel. 2010. Development of extender based on soybean lecithin for its application in liquid ram semen. Theriogenology 74:663-671.

Forouzanfar, M., M. Sharafi, S.M. Hosseini, S. Ostadhosseini, M. Hajian, L. Hosseini, P. Abedi, N. Nili, H.R. Rahmani,\& M.H. Nasr-Esfahani. 2010. In vitro comparison of egg yolk-based and soybean lecithinbased extenders for cryopreservation of ram semen. Theriogenology 73:480-487.

Graham, J.K. \& R.H. Foote. 1987. Effect of several lipids, fatty acyl chain length and degree of unsaturation on the motility of bull spermatozoa after cold shock and freezing. Cryobiology 24:42-52.

Hirai, M., W.A. Cerbito, M.P.B. Wijayagunawardane, J. Braun, W. Leidl, K. Ohosaki,T. Matsuzawa, K. Miyazawa, \& K. Sato. 1997. The effect of viscosity of semen diluents on motility of bull spermatozoa. Theriogenology 47:14631478.

Kmenta I, C. Strohmayer, F. Müller-Schlosser, \& S. Schafer-Somi. 2011. Effects of a lecithin and catalase containing semen extender and a second dilution with different enhancing buffers on the quality of cold-stored canine spermatozoa. Theriogenology 75:1095-1103.

Kumaresan, A., M.R. Ansari, \& G. Abhishek. 2005. Modulation of post-thaw sperm functions with oviductal proteins in buffaloes. Anim. Reprod. Sci. 90:73-78.

Maxwell, W.M.C. \& P.F. Watson. 1996. Recent progress in the preservation of ram semen. Anim Reprod Sci.42:55-65.

Mostafa, A.A., M.S. El-Belely, Ismail, R.I. ElSheshtawy, \& M.I. Shahba. 2018. Impact of replacing egg yolk with lecithin on quality of pre-freeze and post-thaw buffalo spermatozoa. Asian Pacific Journal of Reproduction 7:254-260

Nishijima, K., S. Kitajima, C. Koshimoto, M. Morimoto, T. Watanabe, J. Fan, \& Y. Matsuda. 2015. Motility and fertility of rabbit sperm cryopreserved using soybean lecithin as an alternative to egg yolk. Theriogenology 84:1172-1175.

Rehman, F.U., M.S. Qureshi,\& R.U. Khan. 2014. Effect of soybean based extenders on sperm parameters of holstein-friesian bull during liquid storage at $4^{\circ} \mathrm{C}$. Pakistan J. Zool. 46:185-189.

Salmani, H., A. Towhidi, M. Zhandi, M. Bahreini, \& M. Sharafi. 2014. In vitro assessment of soybean lecithin and egg yolk based diluents for cryopreservation of goat semen. Cryobiology 68:276-280.

Singh, A.K., V.K. Singh, B.M., Narwade, T.K. Mohanty, \& S.K. Atreja. 2012. Comparative quality assessment of buffalo (Bubalus bubalis) semen chilled $\left(5^{\circ} \mathrm{C}\right)$ in egg yolk- and soya milk-based extenders. Reprod. Dom. Anim. 47:596600.

Vick, M.M., H.L. Bateman, C.A. Lambo, \& W.F. Swanson. 2012. Improved cryopreservation of domestic cat sperm in a chemically defined medium. Theriogenology 78:2120-2128. 
Vishwanath R, Shannon P, 2000: Storage of bovine semen in liquid and frozen state. Animal Reproduction Science 62:23-53.

Zhang, S.S., J.H. Hu, Q.W. Li, Z.L. Jiang, \& Z. Xiaoying. 2009. The cryoprotective effects of soybean lecithin on boar spermatozoa quality. Afr. J. Biotechnol. 8:6476-6480. 